\title{
MULTIPLE STRATEGIES FOR EFFECTIVE PATHOGEN CONTROL
}

\author{
T.M. SPIERS ${ }^{1}$, P.A.G. ELMER ${ }^{1}$, P.N. WOOD ${ }^{2}$, T. REGLINSKI ${ }^{1}$ \\ and K.G. TATE ${ }^{3}$
}

${ }^{1}$ HortResearch, Private Bag 3123, Hamilton, New Zealand

${ }^{2}$ HortResearch, Private Bag 1401, Havelock North, New Zealand

${ }^{3}$ Crop Health Services, 204 Riverview Rd, Huntly, New Zealand

Corresponding author: pelmer@hortresearch.co.nz

\begin{abstract}
Market tolerance of fungicide residues on fruit is declining and alternative disease control strategies are required. An integrated management system to reduce and ultimately replace fungicides with acceptable alternatives is being developed. The components include improved knowledge of pathogen epidemiology thereby optimising the timing of fungicides, manipulation of tree nutrition to enhance fruit disease resistance, biological control, inoculum removal strategies to reduce disease risk and postharvest treatment for improved storage life. The integration of these disease management tools provides the basis for consistent and more effective disease control. This paper describes research with Monilinia fructicola, the cause of brown rot in summerfruit, to highlight the benefits of this multi-faceted approach. Green immature fruit (pre-pit hardening) were susceptible to infection highlighting the need for fruit protection at this stage. Foliar calcium, biological control, inoculum removal and postharvest treatment each significantly reduced brown rot incidence but field validation of a combined approach is still required.
\end{abstract}

Keywords: integrated, disease control, biological control, stonefruit, brown rot.

\section{INTRODUCTION}

Disease control in fruit crops worldwide largely relies on the use of fungicides, but this practice is becoming less acceptable to consumers. Disease resistant varieties can reduce losses, but are not readily available in many fruit crops. Biological control offers an acceptable alternative control strategy, but successful commercialisation is very difficult and expensive (Elad \& Stewart 2004). In New Zealand two products, BOTRY-Zen ${ }^{\circledR}$ (Elmer et al. 2003) and Sentinel ${ }^{\circledR}$, have been developed for control of Botrytis in grapes.

Disease control with reduced fungicide applications or using biological control agents (BCAs) is more effective and consistent when an integrated management system is used to lower the pathogen population. This approach is universally accepted by Integrated Pest Management (IPM) workers, but the deployment of multiple strategies (e.g. biological, cultural, physical and chemical tools) for disease management is less common (Jacobson et al. 2004). Two exceptions are the work of Landa et al. (2004) and Wilcox et al. (1999). The challenge for IPM workers has been the development of effective, reliable and cost-effective strategies that can operate additively and synergistically to significantly reduce losses due to fruit rots.

A range of strategies has been tested in stonefruits to control brown rot, caused by Monilinia fructicola (Wint.) Honey. The strategies include improved knowledge of pathogen epidemiology to optimise timing of fungicides, manipulation of tree nutrition to enhance fruit disease resistance, the use of BCAs and elicitors to replace fungicides, 
removal of inoculum sources from the orchard and postharvest treatment using residuefree sanitisers for improved storage life. Examples of studies conducted over 6 years (1999-2005) in two regions (Hawke's Bay and Central Otago) are used to illustrate this approach.

\section{Fruit susceptibility studies}

\section{MATERIALS AND METHODS}

The susceptibility of fruit to infection by $M$. fructicola was assessed by collecting 100 nectarine fruit (cv. Fire Pearl) at intervals from 1 week post shuck fall to harvest and artificially inoculating them with conidia of $M$. fructicola. Fruit were lightly misted with either sterile distilled water ( $\mathrm{n}=50$ fruit) or a suspension of $1 \times 10^{5}$ spores $/ \mathrm{ml}(\mathrm{n}=50)$ using an airbrush and incubated at high humidity at $15^{\circ} \mathrm{C}$ for $24 \mathrm{~h}$ followed by $18 \mathrm{~h}$ at $15^{\circ} \mathrm{C}$ at low humidity to simulate a severe brown rot infection period (Tate et al. 1995). After incubation, fruit were triple surface sterilised (30 sec in $70 \%$ ethanol, $5 \mathrm{~min}$ in $0.45 \%$ sodium hypochlorite and $30 \mathrm{sec}$ in $70 \%$ ethanol), rinsed in running tap water then frozen for 24 to $48 \mathrm{~h}$ to accelerate pathogen expression. The incidence of brown rot latent infections was then assessed visually after 8 days at $12^{\circ} \mathrm{C}$.

\section{Enhancing fruit resistance to infection}

Nectarine trees (cv. Fire Pearl) at the Lawn Road Research Centre, Hawke's Bay, were sprayed with calcium $(\mathrm{Ca})$ chloride solution on six occasions between shuck fall and harvest in both 2003/04 and 2004/05. Control trees did not receive Ca. The application rate was 5 litres/ha for the first three sprays and 10 litres/ha for the last three sprays $(\mathrm{Ca}$ concentration $=17.5 \mathrm{~g} \mathrm{Ca} / 100 \mathrm{ml})$. A brown rot fungicide program using thiram, tebuconazole and cyprodinil at blossom and captan and iprodione pre-harvest was applied over the whole block at standard label rates. At harvest, fruit (1000 in 2003/04, 2000 in $2004 / 05$ from each $\mathrm{Ca}$ treatment) were coolstored for $17-21$ days at $1-2^{\circ} \mathrm{C}$ then for 3 days at room temperature to simulate shelf life conditions. Brown rot incidence was visually assessed after both coolstorage and incubation.

\section{Removal of pathogen inoculum}

A peach orchard (cv. Golden Queen) with a history of brown rot problems was selected in Hawke's Bay. Fruit with visible brown rot infections were either removed or not removed (usual grower practice) from each of six plots of 60 trees on three occasions 1-2 weeks pre-harvest in 2001/02. The grower applied fungicides to the whole orchard and immediately after harvest the number of fruit with typical brown rot symptoms left on the tree by the pickers were counted.

\section{Integrating an elicitor and fungal antagonist for brown rot suppression}

A biological control treatment, comprising a selected fungal antagonist of $M$. fructicola (BCA) and elicitor combination was applied twice over flowering at full bloom and petal fall. The elicitor was then applied 21, 14 and 7 days pre-harvest to single tree plots in a block of peach cv. Golden Queen in 1999/2000 and 2000/01 at the Lawn Road Research Centre, Hawke's Bay. Other treatments included an industry standard brown rot fungicide program (tebuconazole applied 2-3 times over flowering and iprodione 2-3 times pre-harvest) and an adjuvant only control (Pulse ${ }^{\circledR}$ Penetrant, which was also used with the elicitor). Treatments were replicated six times. After the flowering sprays, 25 flowers per plot were sampled at random then incubated in high humidity chambers at room temperature for 2 days and assessed for blossom blight incidence with the aid of a stereo binocular microscope. At harvest, the number of infected fruit per tree was assessed visually.

\section{Suppression of postharvest brown rot development}

Rovral ${ }^{\circledR}$ dips effectively suppresses postharvest brown rot but this practice is no longer acceptable (G. Tate \& P. Elmer, unpubl. data). Apparently healthy nectarine fruit (cv. Fire Pearl) were collected at harvest from a commercial orchard in Hastings in the 2002/03 season. Since, brown rot incidence in the orchard was low, fruit were artificially inoculated by spraying a conidial suspension of $M$. fructicola $\left(6 \times 10^{4}\right.$ spores $\left./ \mathrm{ml}\right)$. Fruit were then dipped in either Proxitane ${ }^{\circledR}$ (a sanitiser based on peracetic acid, hydrogen peroxide 
and acetic acid), iprodione (Rovral ${ }^{\circledR}$ Gold at $50 \mathrm{mg} /$ litre for $1 \mathrm{~min}$ ) or water. Undipped fruit, both inoculated and uninoculated were included for comparison. Each treatment consisted of 20 fruit and was replicated three times. The experiment was repeated and each was completed within the same day. Concentration of Proxitane ${ }^{\circledR}$ and dipping time had been optimised at $0.6 \%$ for 2 min for this cultivar in previous experiments (G. Tate \& P. Elmer, unpubl. data). Following treatment, fruit were allowed to dry, packed in single layer Plix ${ }^{\circledR}$ trays, sealed in a plastic bag, then incubated at room temperature for 6 days before visual assessment of brown rot incidence.

\section{Fruit susceptibility studies}

\section{RESULTS AND DISCUSSION}

Fruit infection by $M$. fructicola varied during the growing season with two peaks of susceptibility, close to pit hardening and prior to fruit harvest (Fig. 1). In contrast to the preharvest period, fungicides are not routinely applied between shuck fall and pit hardening, therefore increasing the probability of latent infection establishment in immature fruit. Similar results have also been reported in other stonefruits elsewhere, including prunes (Luo \& Michailides 2001) and peaches (Mari et al. 2003). The relationship between early season latent infection and brown rot at harvest is complex and not well understood, as not all immature green fruit with latent infections develop brown rot symptoms at harvest (Wade \& Cruickshank 1992). Improved understanding of this relationship is currently being investigated with nitrate non utilising (Nit) mutant strains of the pathogen (Beever \& Parkes 2003) to more clearly define latent infection, crop loss relationships and improve early season fungicide timing.

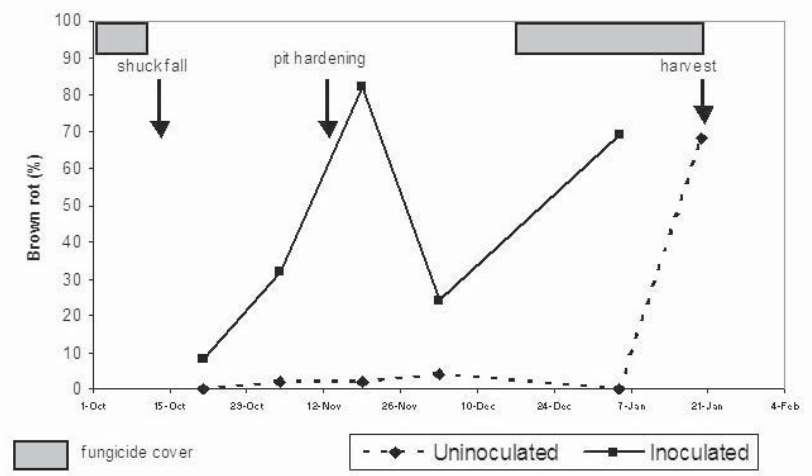

FIGURE 1: Brown rot incidence (\%) of nectarine fruit (cv. Fire Pearl) in relation to crop phenology (2003/04) and current recommendations for fungicide application.

\section{Enhancing fruit resistance to infection}

Fruit from trees sprayed with $\mathrm{Ca}$ had less brown rot compared to fruit that did not have $\mathrm{Ca}$ applications (Table 1). However, the differences were not always statistically significant $(\mathrm{P}<0.05)$. Greater reductions in brown rot $(51-61 \%)$ were achieved when disease pressure was low (2004-05 season) compared to the previous season (2003-04), where disease pressure was considerably higher (range of brown rot reduction $=7-31 \%$ ). Season to season variation in brown rot reduction with Ca has also been reported in other summerfruit crops (Wojcik 2001). It should be noted that there was a high incidence of brown rot in the 2003-04 season despite the application of a recommended export spray programme. 
TABLE 1: Incidence of brown rot (\%) in nectarine cv. Fire Pearl from calcium sprayed or unsprayed trees immediately after coolstorage and 3 days incubation at room temperature in 2003/04 and 2004/05.

\begin{tabular}{lccccc}
\hline & \multicolumn{2}{c}{$2003 / 04$} & & \multicolumn{2}{c}{$2004 / 05$} \\
\cline { 2 - 3 } \cline { 5 - 6 } Ca treatment & Coolstore & Coolstore+shelf & & Coolstore & Coolstore+shelf \\
\hline Plus & 30.0 & 71.4 & & 0.90 & 5.55 \\
Minus & 43.3 & 77.1 & & 2.33 & 11.40 \\
LSD $(\mathrm{P}<0.05)$ & 16.0 & 13.2 & & 1.59 & 5.01 \\
\hline
\end{tabular}

Several mechanisms have been proposed to account for reduced disease development following Ca treatment. These vary from direct effects on the pathogen itself, such as interference with pathogenesis-related enzyme production (Biggs et al. 1997), to indirect effects, such as reduced fruit surface micro-cracks (Børve et al. 2000) and enhanced cell wall resistance to pathogenic enzymatic digestion (Miceli et al. 1999). The present study indicates that the greatest benefits from Ca treatment are likely to occur when pathogen inoculum in an orchard is maintained at low levels (see below).

Removal of pathogen inoculum

An earlier study clearly demonstrated that removal of infected fruit from trees was cost effective ( $\$ 0.50 /$ tree) and could be carried out with conventional hydraulic ladder equipment (P. Wood, unpubl. data). With no inoculum removal (normal practice) the incidence of brown rot was $14.8 \%$, compared to $3.1 \%$ where there was no removal of infected fruit $(\operatorname{LSD}(\mathrm{P}=0.05)=9.2)$. These results indicate that removal of brown rot infected fruit is a practical, cost-effective disease control practice. Reduction of inoculum pressure is a key to successful implementation of biocontrol (O'Neill et al. 1996).

Integrating an elicitor and fungal antagonist for brown rot suppression

The biological control and fungicide treatments effectively suppressed blossom blight compared to the 'untreated' Pulse ${ }^{\circledR}$ control in 1999/2000, but neither programme significantly $(\mathrm{P}<0.05)$ reduced blossom blight in 2000/01 (Table 2). The fungicide and biological control programmes significantly $(\mathrm{P}<0.05)$ reduced brown rot at fruit harvest in both seasons (Table 2) and indicates that biological control provides an effective alternative to synthetic fungicide inputs.

TABLE 2: Blossom blight (\%) and brown rot (\%) in peaches (cv. Golden Queen) with a biological control programme in comparison with a spray programme recommended for brown rot control in Hawke's Bay.

\begin{tabular}{|c|c|c|c|c|}
\hline \multirow[b]{2}{*}{ Treatment } & \multicolumn{2}{|c|}{$1999 / 2000$} & \multicolumn{2}{|c|}{$2000 / 01$} \\
\hline & Blossom blight & Brown rot & Blossom blight & Brown rot \\
\hline Pulse ${ }^{\circledR}$ control & 38 & 41 & 15 & 35 \\
\hline Fungicide & 1 & 6 & 4 & 7 \\
\hline BCA / elicitor & 8 & 17 & 6 & 13 \\
\hline LSD $(\mathrm{P}<0.05)$ & 17.4 & 19.3 & ns & 21.6 \\
\hline
\end{tabular}

\section{Suppression of postharvest brown rot development}

When weather conditions favour brown rot development preharvest, conidia of M. fructicola accumulate on the fruit surface, increasing the risk of postharvest brown rot infection (Bryde \& Willets 1977). A postharvest treatment (Proxitane ${ }^{\circledR}$ ) has been identified that was as effective as Rovral® (G. Tate \& P. Elmer, unpubl. data). Unlike many synthetic fungicides, Proxitane ${ }^{\circledR}$ leaves no undesirable residues, since the breakdown products are water, $\mathrm{CO}_{2}$ and traces of acetic acid. Fruit artificially inoculated then dipped in Proxitane ${ }^{\circledR}$ developed significantly $(\mathrm{P}<0.05)$ less brown rot in storage (7\%) compared to fruit that were dipped in water (85\%, Experiment 1, Table 3). In a 
repeat experiment (Experiment 2, Table 3), postharvest Proxitane ${ }^{\circledR}$ treatment reduced brown rot to $7 \%$ and was equivalent to the fungicide, Rovral ${ }^{\circledR}(12 \%)$.

However, in another experiment Proxitane ${ }^{\circledR}$ was ineffective (90\% rot compared to $40 \%$ for Rovral ${ }^{\circledR}$ and $100 \%$ for undipped) when a processing peach cv. Golden Queen was tested. This fruit had high levels (93\%) of latent brown rot infections prior to dipping and these results indicate that Proxitane ${ }^{\circledR}$ is effective against fruit surface inoculum but ineffective against latent infections.

TABLE 3: Incidence of brown rot $(\%)$ in nectarine (cv. Fire Pearl) fruit after postharvest treatment in $2002 / 03$.

\begin{tabular}{lcccc}
\hline Postharvest & $\begin{array}{c}\text { Dip time } \\
\text { treatment }\end{array}$ & $\begin{array}{c}\text { Inoculation with } \\
\text { (min) }\end{array}$ & M. fructicola & \multicolumn{2}{c}{ Incidence of postharvest brown rot } \\
\cline { 3 - 5 } None & - & Yes & 100 & Experiment 1 \\
Water & 2 & Yes & 85 & 93 \\
Proxitane & 2 & Yes & 7 & 87 \\
Rovral Gold & 1 & Yes & 28 & 7 \\
None & - & No & 17 & 12 \\
LSD $(\mathrm{P}<0.05)$ & & & 16.4 & 37 \\
\hline
\end{tabular}

Effective disease management in the future will be dependent upon the deployment of multiple strategies. While individual strategies may not substantially and consistently reduce disease risk, the combination of several strategies is more likely to be successful. This paper has described a range of strategies that have been individually field-evaluated to suppress brown rot in stonefruit. Comparative studies of a fully integrated brown rot management programme are now required to validate this approach. The strategies described here could easily be applied to manage diseases in organic and conventional fruit crops.

\section{ACKNOWLEDGEMENTS}

We thank FRST, Summerfruit NZ, Heinz Wattie NZ Ltd and AGMARDT for funding this research. We also thank Dr Jill McLaren (HortResearch, Clyde) for valuable assistance with the fruit infection studies. We are also grateful to Frank Parry, Ron Marsden, Joseph Taylor, Brent Fisher, Sarah Gurnsey and Jenny Fraser for providing valuable technical assistance with this research programme and to summerfruit growers in the Hawke's Bay and Central Otago regions for their generous provision of fruit, orchard blocks, support and encouragement throughout this research programme.

\section{REFERENCES}

Beever RE, Parkes SL 2003. Use of nitrate non-utilising (Nit) mutants to determine vegetative compatibility in Botryotinia fuckeliana (Botrytis cinerea). European Journal of Plant Pathology 109: 607-613.

Biggs AR, El-Kholi MM, El-Neshawy S, Nickerson R 1997. Effects of calcium salts on growth, polygalacturonase activity, and infection of peach fruit by Monilinia fructicola. Plant Disease 81: 399-403.

Børve J, Sekse L, Stensvand A 2000. Cuticular fractures promote postharvest fruit rot in sweet cherries. Plant Disease 84: 1180-1184.

Byrde RJ, Willets HJ 1977. The Brown Rot Fungi of Fruit. Their Biology and Control. Pergamon Press, Oxford, UK.

Elad Y, Stewart A 2004. Microbial control of Botrytis spp. In: Elad Y, Williamson B, Tudzynski P, Delan N ed. Botrytis: Biology, Pathology and Control. Kluwer Academic, Dordrecht, The Netherlands. Pp. 223-241. 
Elmer PAG, Reglinski T, Wood PN, Hill RA, Marsden SM, Parry F, Taylor JT 2003. Suppression of Botrytis in grapes using a combination of elicitors and fungal antagonists. 8th International Congress of Plant Pathology. Christchurch, New Zealand. Volume 2 (Offered papers): 43.

Jacobsen BJ, Zidack NK, Larson BJ 2004. The role of Bacillus-based biological control agents in integrated pest management systems: Plant diseases. Phytopathology 94: $1272-1275$.

Landa BB, Navas-Cortes JA, Jimenez-Diaz RM 2004. Integrated management of Fusarium wilt of chickpeas with sowing date, host resistance and biological control. Phytopathology 94: 946-960.

Luo Y, Michailides TJ 2001. Factors affecting latent infection of prune fruit by Monilinia fructicola. Phytopathology 91: 864-872.

Mari M, Casalini L, Baraldi E, Bertolini P, Pratella GC 2003. Susceptibility of apricot and peach fruit to Monilinia laxa during phenological stages. Postharvest Biology and Technology 30: 105-109.

Miceli A, Ippolito A, Linsalata V, Nigro F 1999. Effect of preharvest calcium treatments on decay and biochemical changes in table grape during storage. Phytopathologia Mediterranea 38: 47-53.

O’Neill TM, Elad Y, Shtienberg D, Cohen A 1996. Control of grapevine grey mould with Trichoderma harzianum T39. Biocontrol Science and Technology 6: 139-146.

Tate KG, Wood PN, Manktelow DW 1995. Development of an improved spray timing system for process peaches in Hawke's Bay. Proceedings of the 48th New Zealand Plant Protection Conference: 101-106.

Wade GC, Cruickshank RH 1992. The establishment and structure of latent infections with Monilinia fructicola on apricots. Journal of Phytopathology 136: 95-106.

Wilcox WF, Pritts MP, Kelly MJ 1999. Integrated control of Phytophthora root rot of red raspberry. Plant Disease 83: 1149-1154.

Wojcik P 2001. "Dabrowicka Prune" fruit quality as influenced by Calcium spraying. Journal of Plant Nutrition 24: 1229-1241. 